\title{
Legal Arrangements of Law Enforcement in the Defense of the State to Strengthen the Defense of the Unitary Republic of Indonesia
}

\author{
Yuliana Yuli W; Satino; Sulastri \\ Universitas Pembangunan Nasional Veteran Jakarta, Indonesia \\ http://dx.doi.org/10.18415/ijmmu.v7i9.1954
}

\begin{abstract}
One of the functions of the state of being very important state on guarantees is a function the defense of the country. Function the defense of the country intended especially for preserves and maintain the country of the list of possibilities under attack by one of the outside and from within. Research methods that were used with the approach is normative juridical approach for legislation statue approach) based on the data found so some conclusion can be drawn as follows: 1.strategy state-defense to strengthen the system which can ensure the defense of the country it has stood the unitary state of the republic of Indonesia (NKRI): a. manifesting the form of the implementation of education state-defense through the activities of education education of citizenship, basic military training, devotion as a soldier tni and devotion befitting a profession . b. realize the implementation of the system of the sense of statedefense through the socialization of the program state-defense to all levels of society. c. create software containing legislation to support the implementation of the program state-defense. Software used as a reference a legal right in carried out a state-defense. d. create the necessary to support the program statedefense, especially to give the consequences to the left temporarily work. The defense of the country strategy which can ensure it has stood the unitary state of the republic of Indonesia (NKRI), at the same time to respond to the challenges the defense of the country in the future, is the application of the system of the defense a strategy of defense in a padded menyinergiskan lapis military defense with layers nonmilitary defense . 2 . The implementation of the policy to strengthen the defense system the unitary state of the republic of Indonesia (NKRI), regulated in the law of no. 13 years 2002 on the defense of the country. Where explained above that bela of the country is the attitudes and behavior a citizen who imbued by take one to the unitary state of the republic of Indonesia that based upon Pancasila and the constitution of 1945 at sustained concern only the survival of the entire nation and the country. The state should know is the right and responsibilities of citizens.
\end{abstract}

Keywords: State Defense; Defense of the Country; Geopolitical

\section{Introduction}

Defending the state is a psychological condition in the form of attitudes and behaviors and responsive actions of every citizen towards a matter that is imbued with his love for the Unitary State of the Republic of Indonesia (NKRI) based on Pancasila and the 1945 Constitution of the Republic of Indonesia in ensuring the survival of the nation and country. 
The discourse on geopolitics emerged before the Proclamation of Independence on August 17, 1945. Geopolitics became a discourse when Ir. Soekarno spoke before the First Session of the BPUPK (Investigation Agency for the Preparation of Independence) on June 1, 1945, which discussed the country's foundation for Indonesia in the future.

When delivering his speech Ir. Soekarno said that Indonesia would be in the form of a national state or nation state. In conveying the concept of the nation state or national state, Ir. Soekarno stressed the Indonesian people to realize the importance of geopolitics, especially in its position as an archipelagic nation situated between two oceans and two continents. Geopolitics is a reference in compiling the basis for the country which is then called Pancasila. With its position as the basis of the state, as stated in the Preamble to the Constitution of the Republic of Indonesia (1945 Constitution), the Pancasila is the highest source of law in the Unitary State of the Republic of Indonesia (NKRI).

As the world's largest archipelago, Indonesia's geographical position stretches to coordinates 6 LU - 11.08 'LS and 95 BT - 141.45' East and is located between two continents, Asia in the north, Australia in the South, and two oceans namely the Indies / Indonesia in the west and Pacific in the east. In a geopolitical perspective, this geographical position certainly makes Indonesia a country that has strategic bargaining power and bargaining positions in the arena and relations between nations, both regionally and globally. This departs from the idea that space is the core of geopolitics because it is a vehicle for political and military dynamics. De facto and de jure control of space. Increased state space or reduced state space by various types of causes, are always associated with the honor and sovereignty of the state and nation. Meanwhile, relations between nations are always colored by competition and cooperation.

In this connection, each nation seeks to achieve and secure its national interests using all its national power instruments. In relation to the national interests, the Indonesian people must of course always develop and have space consciousness and geographical awareness as an archipelagic nation.

This is logical and very basic considering, on the one hand, the strategic and open geographical position and containing the diversity of potential natural resources, of course, is an opportunity and advantage for the Indonesian people in realizing their national ideals and goals. But on the other hand, the geographical position which is the crossing and meeting of the interests of various countries, also contains vulnerability and vulnerability due to the influence of the development of a strategic environment that can develop into a threat to national defense and national defense.

\section{According to Winarno:}

"Defending the country is the attitude and actions of citizens based on a sense of patriotism, national and state awareness, belief in Pancasila as an ideology of the nation and state, willingness to sacrifice to face threats, challenges, obstacles, and disturbances (ATHG) both that come from within and from outside which endangers the survival of the nation and state, territorial integrity, national jurisdiction and the noble values of the Pancasila and the 1945 Constitution as the state constitution ".

The above understanding certainly provides the widest opportunity for every citizen to be able to carry out state defense activities in accordance with their respective abilities in their fields.

The achievement of national goals is also greatly influenced by the dynamics of geopolitics and the insight of the archipelago or the way of the Indonesian people about themselves and the environment of their existence.

To be able to anticipate the dynamics of geopolitics in order to achieve national goals requires a resilience or tenacity that departs from the Archipelago's Insight. In this context, the Indonesian nation needs a resilience to National Resilience, namely the dynamic condition of the Indonesian nation which 
covers all aspects of national life that are integrated and contains resilience and resilience which contains the ability to develop national strength in facing and overcoming all challenges, threats, obstacles and disturbances both coming from outside or inside, to guarantee the identity, integrity, survival of the nation and state, and the struggle to achieve its national goals.

To achieve national goals, the astra gatra who make up National Resilience need an integrated implementation system that refers to geopolitical dynamics. The integrated system can be outlined in a state defense system that already has a strong legal basis in the 1945 Constitution, as well as Law Number 3 of 2002 concerning National Defense (Law No. 3/2002), Article 9 of Law Number 3 of 2002 states:

(1) Every citizen has the right and obligation to participate in efforts to defend the state which is realized in the implementation of national defense;

(2) The participation of citizens in efforts to defend the country, as meant in paragraph (1), is carried out through:

a. Civic education;

b. Mandatory military basic training;

c. Serving as a soldier of the Indonesian National Army voluntarily or compulsorily; and

d. Dedication in accordance with the profession.

The concept of national defense itself implies participation in national defense, which includes: maintaining the independence and sovereignty of the country, territorial integrity, and the safety of the nation from all threats. While the form of defense of the state in the form of rights and obligations through citizenship education, service as a TNI soldier and service according to the profession. Despite having a solid legal basis, until now Indonesia does not yet have a comprehensive state defense implementation system.

Defending the country that we can now understand physically and non-physically. The physical defense of the state is a citizen who advances war by carrying a weapon, while non-physical defense is a defense of the state carried out by citizens without taking up arms, but through an attitude of patriotism, national and state awareness, willingness to sacrifice, and confident of Pancasila as the state ideology, and obey the applicable legal rules. Therefore, the study of the meaning of state defense can also be understood from various aspects (perspectives), including aspects of the region, aspects of citizenship law, and aspects of national security.

In the regional perspective, the meaning of defending the country as an attitude and action of people (residents) from whatever origin (native / immigrant) who settled in certain areas to maintain, protect, and be responsible for the sustainability of their territory.

In the perspective of citizenship law, the meaning of foreign affairs is related to the legal status of citizens (WNI and WNA), meaning that those who are entitled and obliged to defend the country are Indonesian citizens (WNI). In the context of aspects of national resilience, the meaning of defending the country becomes an attitude and action that reflects the strength and resilience of a nation and state in protecting and protecting the territory of the country as a whole.

At present the defense of the state is intended to strengthen the sense of nationalism and the spirit of patriotism of Indonesian citizens in the midst of the current threat to the nation in the form of international and national terrorism crimes, acts of racial violence, violations of state territory both on land, sea, air and space, separatist movements, transnational crime and disruption, and environmental destruction. 
The process of understanding the meaning of state defense is currently felt to be difficult, especially in pluralistic societies that in principle and humanity sometimes show selfish attitudes and actions, such as the emergence of egoistic / individual attitudes, ethnicism, apathy, which makes the process of national integration slow. Without the ability to defend themselves, a country will not be able to maintain its existence or existence.

Third, the social contract, the Indonesian people proclaimed their independence on August 17, 1945, determined to defend, maintain and uphold independence, and state sovereignty based on Pancasila and the 1945 Constitution.

Fourth, moral considerations, independence is the right of all nations and therefore colonialism over the world must be abolished because it is incompatible with humanity and justice.

Fifth, legal or juridical provisions, including 1) 1945 Constitution Article 27 Paragraph (3): "That every citizen behaves and is obliged to participate in efforts to defend the country", 2) 1945 Constitution Article 30 Paragraph (1) and (2) " That every citizen has the right and duty to participate in the National Defense and Security effort, and the National Defense and Security Effort is carried out through the Universal People's Defense and Security System by the TNI and the Police as the Main Component, the People as a Supporting Component.

In addition (3) Law No. 39 of 1999 concerning Human Rights Article 6B: "Every citizen is obliged to participate in efforts to defend the country, in accordance with applicable provisions", 4) Law No.3 of 2002 concerning National Defense Article 9 Paragraph (1) "Every citizen entitled and obliged to participate in efforts to defend the state which is realized in the Implementation of National Defense ", and 5) Law No.3 of 2002 Concerning National Defense Article 9 Paragraph (2)" The participation of citizens in the effort to defend the country referred to in paragraph (1) is carried out through citizenship education, basic military training, voluntary or compulsory service as a TNI soldier and service in accordance with the profession. According to Notonagoro, a philosopher and law expert from Gajah Mada University, nationalism in the context of Pancasila is "single compound" (unity in diversity). The elements that make up Indonesian nationalism are as follows:

1. Historical Unity. namely the unity formed in the course of its long history since the days of Srivijaya, Majapahit and the emergence of Islamic empires until finally the occupation of the VOC and the Dutch. Openly, nationalism first began in the Youth Oath on October 28, 1928 and reached its peak at the Proclamation of Indonesian Independence on August 17, 1945.

2. Unity of Fate. The Indonesian nation was formed because it had the same fate, namely suffering during the colonial period and the struggle for independence separately and together.

3. Cultural Unity. Although the Indonesian people have a diversity of cultures and adhere to different religions, but overall it is an allied culture and has links with the major religions of the Indonesian people.

4. Regional Unity. This nation lives and looks for livelihood in the same region, namely the blood of Indonesia.

5. Unity of Spiritual Principle. This nation has the same ideals, outlook on life and state philosophy rooted in the outlook of life of the Indonesian people themselves in the past and at present.

For the Indonesian people,quoting social historian Charles Tilly,our nationalism is "state-led nationalism". 
A kind of nationalism built from above, and then sliding down. That is, the state must shape its character and character and give direction to the nation's children. The state must construct the concept of nationalism as a "common project" for all its citizens. However, what is sought by the state must of course be understood, understood and supported by all the children of the nation without exception.

For the Indonesian people, war is the last resort that must be taken to defend the state ideology, independence and sovereignty of the Republic of Indonesia. The doctrine and system of the Indonesian National Defense implicitly reflects the view of the Indonesian people about the concepts of war and peace, namely "the Indonesian people love peace, but more love independence"

Therefore, the Indonesian people did not develop the doctrine of power and power struggle, because it contained the seeds of dispute, hostility and expansionism. Indonesia develops and organizes its country's defense system in a nuance of openness, which is an embodiment of the principle of peace-loving and wants to live in harmony with other countries.

The attitudes and perspectives of the Indonesian Nation reflect the view of the Geopolitics and Geostrategic of the Indonesian nation, which was clearly outlined in the 2008 Indonesian Defense White Paper. As an elaboration of the constitution on the defense aspect, the Indonesian Nation has compiled Law Number 3 of 2002 concerning National Defense which stipulates that the Indonesian State Defense System is a universal defense system involving all citizens, territories and other national resources.

This is an effort to synergize the performance of the Military and Nir Military components in order to protect, protect and preserve Indonesia's national interests. The Universal Defense System combines military defense and non-military defense which support each other in upholding the country's sovereignty, the territorial integrity of the Republic of Indonesia, and the safety of all nations from all threats.

In RI Law No. 3/2002 concerning National Defense it is emphasized that as a manifestation of totality, the involvement of all citizens in the defense of the state is both an obligation and a right. The National Defense Law also classifies that national defense forces are classified into three groups, namely the Main Component (TNI), the Reserve Component and the Supporting Component.

In implementing a state defense, a citizen can do it both physically and non-physically. The physical defense of the state includes the struggle to take up arms if there is an attack from a foreign country against national sovereignty. Meanwhile, non-physical defense of the state is defined as all efforts to safeguard the nation and state sovereignty through a process of increasing nationalism. Nationalism is a series of love and awareness in the process of life in the country and nation, and efforts to foster a sense of love for the motherland. In addition, the defense can be done by fostering active involvement in an active role to realize the progress of the nation and state.

The national defense strategy that can guarantee the establishment of the Unitary Republic of Indonesia (NKRI), as well as responding to the challenges of national defense going forward, is the application of the Universal Defense System in the form of a Layered Defense Strategy which synergizes the military defense layer with the non-military defense layer.

Such state defense awareness is very important for the survival or existence of a nation. But in reality, national and state awareness is still very thin or low, said Ryamizard Ryacudu as the Minister of Defense of the Republic of Indonesia when he was the keynote speaker at the Coordination Meeting of the Coordination of Defense of the National Defending State with Governors and Chancellors throughout Indonesia, Thursday, August 25, 2016 at the Bhinneka Building Tunggal Ika Ministry of Defense Republic of Indonesia, Jalan Medan Merdeka Barat No. 13-14 Jakarta. 
Defending the State is a concept developed by a set of laws and officials of a country about the patriotism of a person, a group or all components of a country in the interests of maintaining the existence of that country.

The basis of the concept of state defense is the existence of conscription. The subject of this concept is the army or other state defense equipment, either as a chosen occupation or as a result of involuntary design (conscription). Some countries (such as Israel, Iran) and Singapore impose compulsory military service for eligible citizens (except by dispensation for certain reasons such as physical, mental or religious beliefs). A nation with fully military volunteers, usually does not require the services of its conscripts, unless faced with a recruitment crisis during wartime.

In Indonesia the process of state defense has been formally regulated in law. Among them have been stated in the Pancasila and the 1945 Constitution, particularly Article 30. In that article, it is explained that defending the nation is an obligation for all Indonesian people without exception.

One of the functions of the state that is very important for guaranteeing the survival of the state is the function of national defense. The function of national defense is intended primarily to protect and defend the country against all possible attacks from outside. Therefore, it must be equipped with defense equipment namely the TNI (Indonesian National Army) and its equipment. The TNI consists of the Army, Navy, and Air Force.

The function of national defense cannot be separated from the defense of the state as affirmed in RI Law No. 3 of 2003 that "every citizen has the right and obligation to participate in efforts to defend the state which is realized in the administration of national defense" (Article 9 paragraph (1)). This implies that the participation of citizens in carrying out the function of national defense is a form of state defense efforts.

In addition to the defense function, another function that is also very important in efforts to defend the state is the security (order) function, which is to prevent clashes in society. In order to carry out this security function in our country an institution known as the Indonesian National Police was formed.

Based on the description above, the function of the state which is very important to maintain order and ensure the survival or upholding of the state is the function of defense and order (security). To realize the function of defense and security, in addition to the state must have defense and security tools, also requires the participation of all citizens in the country's defense and security efforts. Thus, the participation of all citizens in carrying out the functions of national defense and security is related to efforts to defend the country.

The function of national defense and security is a very important function in the life of the state and is a prerequisite for other functions. That is because the state can only carry out other functions if the state is able to defend itself from various threats both from outside and inside.

The importance of defense and security functions in national life can be compared to our daily personal lives. Likewise, in state organizations, the defense and security function is very important because the state will not be able to prosper the people, improve the quality of education, uphold justice, and others if it is unable to defend itself against threats from both outside and inside.

This implies that to defend and secure the state is not only an obligation of the TNI and POLRI, but also an obligation of every Indonesian citizen including you as students who are also citizens of Indonesia. 
Whereas the welfare and prosperity functions are carried out by the government in the form of services and commerce. Service functions or services that are all activities that might not exist if not carried out by the state, which include maintenance of the poor, road construction, bridge construction, health, education, and other development programs.

Based on the above background description, the author gives the title of this description: Legal arrangements of Law Enforcement of the Defending the State in order to Strengthen the Defense of the Unitary Republic of Indonesia.

\section{Formulation of the Problem}

The formulation of this research problem is:

1. How is the defense strategy in strengthening the national defense system that can guarantee the establishment of the Unitary Republic of Indonesia (NKRI)?

2. How is the implementation of state defense policy in strengthening the defense system of the Unitary Republic of Indonesia (NKRI)?

\section{Research Purposes}

The objectives of this study are as follows:

1. To know the strategy of defending the country in strengthening the national defense system that can guarantee the establishment of the Unitary Republic of Indonesia (NKRI).

2. To find out the implementation of state defense policies in strengthening the defense system of the Unitary Republic of Indonesia (NKRI).

\section{Benefits of Research}

This research has two benefits, namely academic benefits and practical benefits.

\section{Theoretical benefits.}

Through this research, it is hoped that it can be useful to increase the repertoire of knowledge in the development of Knowledge Management on state defense arrangements to strengthen the legal system in the field of national defense.

\section{Practical benefits.}

The results of the study are expected to provide benefits to the community and can increase awareness of the law of state defense for all citizens of the Republic of Indonesia.

\section{Literature Review}

National Defense is the attitude and behavior of citizens imbued with their love for the Unitary State of the Republic of Indonesia based on the Pancasila and the 1945 Constitution in establishing the survival of the nation and the whole nation. Every citizen has the right and duty to participate in the defense of the state and the requirements for defense are regulated by law. 
Efforts to defend the country apart from being a basic obligation are also an honor for every citizen that is carried out with full awareness, responsibility and is willing to sacrifice in the service of the state and nation. Our participation in defending the country is a form of love for our homeland to the country. Creating a strong state resilience system is through State Defense Education.

The meaning of the defense of the State is always perceived as being related to the efforts of the Indonesian people to face threats to the survival of the Indonesian nation in the following periods:

1. The first period of the independence war (1945 - 1949).

Defending the country is perceived as a war of independence. This means that the participation of citizens in defending the country is manifested as participating in the war for independence, both armed and unarmed.

2. The second period (1950 - 1965).

In the face of various rebellions and disturbances in domestic security, defending the country is perceived as synonymous with defense and security efforts, both armed and unarmed.

3. The third period (New Order 1966 - 1998).

In an effort to face ATHG, a concept of national resilience was developed and applied. Therefore, the defense of the state is perceived to be synonymous with national resilience. In this period the participation of citizens in defending the country was carried out through all aspects of national life.

4. The fourth period (Reform Order 1998 - present).

Defending the country is perceived as an effort to overcome the various crises that are being faced by all Indonesians. In this period, the participation of every citizen in defending the country is adjusted to their abilities and professions.

Awareness of national defense is essentially the willingness to serve the country and the willingness to sacrifice to defend the country. The country's defense spectrum is very broad, from the subtlest, to the loudest. Starting from good relations among citizens to jointly ward off the real threat of armed enemies. This includes acting and doing the best for the nation and state. Element of Defending Country include:

\section{a) Love the Motherland}

This state defense program will also emphasize the importance of cultivating the attitudes and behaviors of patriotism. This is in accordance with the definition of state defense, namely the attitudes and behavior of Indonesian citizens who are imbued with the love of the motherland based on Pancasila and the 1945 Constitution in ensuring the survival of the nation and state.

\section{b) National \& State Awareness}

The defense of the state is usually always associated with the military or militarism, as if the obligation and responsibility to defend the state rests only with the TNI. The national defense program also focuses on the awareness of defending the state which is an essential thing that must be possessed by every Indonesian citizen, as a form of fulfilling his rights and obligations in the effort to defend the country. Awareness of national defense becomes the basic capital as well as the strength of the nation, in 
order to maintain the integrity, sovereignty and survival of the Indonesian nation and state.

c) Convinced of Pancasila as the state ideology

The values developed in the state defense program are convinced of Pancasila as a state ideology, one of the strategies in building the nation's deterrence to deal with the complexity of threats. This strategy will be realized if there is integration in cross-sectoral implementation, as a form of joint responsibility for fostering human resources to realize the integrity and survival of the Unitary Republic of Indonesia. It is hoped that there is an understanding that fostering awareness of defending the country as an effort to build the character of the Indonesian nation.

d) Willing to sacrifice for the nation \& state

The state defense program also fosters citizens to have a life that is willing to sacrifice for the nation and state, which is willing to sacrifice time, energy and thoughts for the advancement of the nation and state, ready to sacrifice body and soul in order to defend the nation and state from various threats, actively participate in community development, nation and state, love to help fellow citizens who are experiencing difficulties and believe and believe that sacrifice for the nation and state is not in vain.

e) Has the initial ability to defend the country

Psychologically, that is having emotional, spiritual and intelligence intelligence, always nourishes the body and soul and has the characteristics of discipline, resilient, hard work and endure the test. While physically, that is having health conditions, and physical skills.

Examples of Country Defense:

a) Practicing Pancasila

b) Learning according to teachings

c) Obey the laws and rules of the country

d) Loving domestic products

e) Defend the Defenders of the Unitary Republic of Indonesia

The five basic values of defending the country should be seen as the virtues of life that must be lived by citizens at all levels. Likewise, education is seen as the most appropriate way or means to make citizens aware of the importance of national defense values. Because as a means of awareness, education illuminates the intellect, arouses and warms the sense of, and reinforces the will of the citizens so that they have a sense of belonging, a sense of responsibility and a high commitment to the destiny of the nation and country.

This is in line with the explanation of the Law of the Republic of Indonesia Number 20 of 2003 concerning the National Education System, Article 37 paragraph (1) explains that citizenship education is intended to shape students into human beings who have a sense of nationality and love for the motherland.

From these explanations, that the formation of a sense of nationality and love of the homeland of students can be fostered through citizenship education. The concept of nationalism and love for the motherland is closely related to the meaning of the country's defense efforts. The concept of state defense is a moral conception that is implemented in the attitudes, behavior and actions of every citizen based on a sense of patriotism, national and state awareness, belief in Pancasila as the state ideology, and a willingness to sacrifice for the nation and state of Indonesia. 
Thus, in relation to defending the country, citizenship education is a vehicle to foster students' awareness to participate in the defense of the state. Considering that the main task carried out by the Ministry of Defense in the defense education of the state defense is to instill the values of the importance of the defense of the state for citizens and is a basic education for citizens, the defense education for the state of defense is actually an inseparable part of citizenship education.

The existence of a state defense awareness education program can make citizens more aware that defending the country is not merely a mandate of the constitution, but rather a mandate of love for the motherland by citizens. This perspective will facilitate citizens in the whole process of education or the formation of national defense awareness.

In this case defending the state is not only seen as a state duty, but also as an honor and trust given by the state to every citizen who should be proud of and carried out with full awareness, responsibility, full of enthusiasm willing to sacrifice for the service of the nation and state.

Through preliminary education learning programs defending the country that can support the achievement of awareness efforts for all individuals as citizens, to better understand and appreciate the importance of the meaning of defending the country. Because in essence education itself is a conscious effort made in order to grow maturity and sense of responsibility.

Threats and challenges that must be considered and at the same time must be faced by all components of the Indonesian nation in growing awareness of the defense of the country, related to the strong current of globalization that has hit the lives of Indonesian people. Because after all, the strong flow of globalization can weaken the awareness of defending the country.

\section{Research Methods}

This type of research is normative legal research that examines law as norms, rules contained in the Law, and various statutory regulations. This normative legal research is a study conducted by studying literature.

\section{Approach Method}

The problem approach used in this study is the normative juridical approach. For this reason, research is needed which is a basic plan in the development of science.

\section{Data Source}

The data source in this study is the subject from which the data was obtained. The data source used in the study was only one, namely secondary data sources. Secondary data is data that includes laws and regulations, official documents, books, research results in the form of reports, diaries and so on. The secondary data in this study were obtained from scientific books, expert opinions, and literature in accordance with the theme in this study.

Secondary data is additional data obtained from various legal materials related to research. Secondary data consists of:

1) Primary Legal Materials, are binding legal materials, including laws, government regulations and others.

2) Secondary legal materials, are materials that are closely related to primary legal materials and can 
help analyze and provide explanations of primary legal materials, which include books, scientific works.

3) Tertiary legal materials, i.e. other materials that have relevance to the subject matter which provide information about primary legal materials and secondary legal materials, such as encyclopedias, dictionaries, articles, newspapers, and the internet.

\section{Research Results and Discussion}

The essence of national resilience is essentially the ability possessed by the nation and state in dealing with all forms of threats, whose spectrum is increasingly broad and complex today. There is a relationship between national defense and state defense or national defense. Defending the country is a manifestation of citizens in an effort to maintain and improve the national resilience of the Indonesian people. The participation of citizens in efforts to face or mitigate threats is carried out in the form of a state defense effort.

State Defending is a concept that is compiled by a set of laws and officials of a country about the patriotism of a person, a group or all components of a country in the interests of maintaining the existence of the state. The state defense program desired by President Jokowi is not like the concept of conscription, but rather resembles character building with patriotic values and optimism in every citizen. The concept of Defending the State is confronted with the readiness of the Pusdikif in carrying out state defense education based on the Idiil Foundation, namely Pancasila and the legal foundation, namely the 1945 Constitution with the aim of fostering nationalist insight, arousing the soul and spirit of nationalism, forming a high attitude of discipline and loyalty against the country.

The national defense strategy that can guarantee the establishment of the Unitary Republic of Indonesia (NKRI), as well as responding to the challenges of national defense going forward, is the application of the Universal Defense System in the form of a Layered Defense Strategy which synergizes the military defense layer with the non-military defense layer.

The Layered Defense Strategy which combines layers of military defense and layers of nonmilitary defense, is a manifestation of the participation of all Indonesian citizens in the efforts of national defense by making maximum use of all national resources. These attitudes and behaviors do not simply emerge into the awareness of every citizen from birth, so they need to be nurtured from an early age and always be nurtured and continually developed through fostering awareness of defending the country.

National Resilience is very dependent on the ability to optimize the function of natural aspects or elements as a basis for creating dynamic aspects which are the strength in the administration of national life. The natural aspect consists of three gatra (tri gatra), namely the geographical gatra, the demographic gatra, and the gatra of natural resource wealth (SKA). While the dynamic aspect consists of five gatra (panca gatra) which includes ideology, political, economic, social and cultural and defense and security. The combination of tri gatra and panca gatra is called asta gatra or eight aspects of National Resilience. To achieve national goals, the asta gatra that compiles National Resilience needs an integrated implementation system that refers to geopolitical dynamics.

Article 9 of Law No. 3 of 2002 states:

(1) Every citizen has the right and obligation to participate in efforts to defend the state which is realized in the implementation of national defense;

(2) The participation of citizens in efforts to defend the country, as referred to in paragraph (1), is carried out through: 
a. civic education;

b. compulsory military basic training;

c. serving as a soldier of the Indonesian National Army on a voluntary or mandatory basis; and

d. service in accordance with the profession.

In explaining how state defense education will provide tangible benefits for the people of Indonesia, we must look at the reality of the challenges and abilities that the state has.

In the national defense policy which refers to Law No. 3 of 2002 concerning National Defense, as stated in the 2015 National Defense White Paper issued by the Ministry of Defense, awareness of the defense of Indonesian citizens is placed in a very strategic position, namely as a foundation / foundation on the pyramid of national defense resources.

Military defense resources are the result of the transformation of the strength of the military defense component which is formed from several state defense forces, including the main components which are strengthened by reserve and supporting components. The main component is the TNI which is ready to be used to carry out defense tasks.

The reserve component consists of citizens, natural resources, artificial resources, and national facilities and infrastructure that have been prepared and organized to be mobilized through mobilization to enlarge and strengthen the main components.

Supporting components consist of citizens, natural resources, artificial resources and national facilities and infrastructure that are prepared and arranged to enhance the strength and capability of the main components and reserve components, directly or indirectly.

In das sollen, defending the state as part of national defense, becomes a decisive factor in ensuring the survival of the nation and state. The state will not be able to survive to maintain its existence without the support of citizen contributions. The state was established for the benefit of citizens who live in it in order to achieve mutual prosperity. But in basic terms, these fundamental interests are not always facilitated by the regulation of legal products, bearing in mind that the law cannot be separated from political influence.

Moh. Mahfud Md stated that the legislative function (law making) owned by members of the council in fact makes more political decisions compared to carrying out legal work that should be, especially if the legal work is associated with procedural issues. It seems clear that the legislative body (which establishes legal products) is actually closer to politics than to the law itself.

The Ministry of Defense has formulated an annual state defense policy as a translation of the 2016 national defense implementation policy and is a reference for the Ministry of Defense and the TNI in carrying out national defense during 2016. The policy covers the areas of strategy, regulation, budgeting, human resources, MEF achievement, infrastructure facilities and management of national defense potential, including the development of the defense industry based on the spirit of national defense in order to create a strong national defense.

There are 9 (nine) main points of the policy of the Minister of Defense which are the Priorities of the Ministry of Defense in 2016. The main points of the policy are directed to accelerate the implementation of maritime defense policy. "The main points of defense policy that become the priority of the Ministry of Defense in 2016 are directed at achieving the acceleration of the implementation of maritime defense policy in the national defense system to support the realization of Indonesia as the world's maritime axis", the ninth are: 
a. Continuing the empowerment and security program for land border areas in Kalimantan and the development of security facilities and infrastructure for land border areas in Papua and East Nusa Tenggara and the outermost / outermost small islands.

b. Second, continuing the development of border areas and outermost / leading small islands (PPKT) especially in Natuna in anticipating the development of the strategic environment.

c. Describe national policies regarding the South China Sea both external and internal policies.

d. Following up on the legislative process of the plan to establish a vertical ministry of defense as an extension of the regional government in the defense sector.

e. Strengthening maritime defense policy which is one of the five pillars of the world maritime axis policy including the development of forces that have the capacity to deter and empower all national maritime strengths and potentials in an integrated and deployed manner in dealing with maritime threats in accordance with laws and regulations both in peacetime and in peacetime wartime.

f. Continuing the policy of developing national defense posture directed according to the scale of priorities, especially in order to anticipate and face real threats.

g. The Alutsista modernization policy is prioritized to face real and unreal threats and face real and unreal threats and strengthen the maritime axis.

h. Describe general policy and implementation of national defense in 2015-2019 by arranging strategic products including doctrine, strategy, posture, MEF, White Paper and the concept of maritime defense to support the vision, mission and program of the cabinet work government, including the policy of the world's maritime axis by utilizing drone system.

Institutional development to strengthen the management of national defense in synergy and integrated in anticipating threats.

To be able to defend the country must have the ability of knowledge, attitudes and skills to defend the country, these abilities can be formed through state defense education through formal, non-formal and informal education. The formal education pathway in schools is given citizenship education starting from primary, secondary to university level. For non-formal education channels in the community, agencies, social organizations and mass organizations. Whereas the informal education pathway is carried out at the family level through exemplary parenting in household life.

Defending the country can be done anytime, anywhere, morning, afternoon or evening, in the household, community, agency / place of work, at school, at a place of worship, at the market, at home and abroad.

State defense activities from the most refined level are positive towards the Unitary State of the Republic of Indonesia to the most violent way to fight enemies who threaten the independence and sovereignty of the Indonesian nation and State. The ideal conditions of defending the country are also defending the government, likewise defending the government also defending the country in these conditions if the government and the state are in line with the ideals and goals of the establishment of the Unitary Republic of Indonesia.

Defending the country is one of the efforts and propaganda carried out by the government to defend the sovereignty of the people in Indonesia. However, that does not mean the government 
arbitrarily and arbitrarily suddenly strives to defend this country. When a government wants to do something, there must be a clear legal basis for something.

Defending the country is a policy. As a policy, then defending the country certainly has a legal basis, a legal basis, and proper and valid regulations. Defending the country is a policy made by the state or government that aims to protect the country from enemy threats that come directly or indirectly.

The defense of the state must be socialized to all components of society in order to be understood and imbued by all components of society, so that all components of society voluntarily defend the country. Defending the State is a concept developed by a set of laws and officials of a country about the patriotism of a person, a group or all components of a country in the interests of maintaining the existence of that country.

Physically, this can be interpreted as a defense effort in the face of physical attacks or aggression from those who threaten the existence of the country, whereas non-physically this concept is interpreted as an effort to play an active role in advancing the nation and state, whether through education, morals, social and improving the welfare of the people who make up the nation.

State Defending is the attitude, behavior and actions of citizens imbued with their love for the Unitary State of the Republic of Indonesia based on the Pancasila and the 1945 Constitution of the Republic of Indonesia in establishing the survival of the nation and the whole nation. The basic law of state defense in Indonesia is very clearly stipulated in various laws and regulations, especially in the 1945 Constitution of the Republic of Indonesia.

NRI 1945 Constitution Article 30 paragraph (1) and paragraph (2) states explicitly about the defense of the state for all Indonesian people, as follows: Article 30 paragraph (1): "Every citizen has the right and obligation to participate in defense efforts and state security ". Article 30 paragraph (2): "Efforts to defend the national security and security are carried out through the defense and security system of the people of the universe by the TNI and Polri as the main force and the people as supporting forces".

Furthermore, in Law No. 3 of 2002 concerning National Defense, Article 9 is clearly mandated about the rules of national defense for the people of Indonesia, as follows: Every citizen has the right and obligation to participate in efforts to defend the country which is manifested in the implementation of national defense.

The participation of citizens in efforts to defend the state, as referred to in Article 30 paragraph (1), is carried out through:

a. civic education;

b. compulsory military basic training;

c. serving as a soldier of the Indonesian National Army on a voluntary or mandatory basis; and

d. service in accordance with the profession.

Provisions regarding citizenship education, compulsory military basic training, and service in accordance with the profession are regulated by law. In more detail, it will be seen the various rules contained in the legal regulation regarding the legal basis for the implementation of state defense in Indonesia, as follows: 
- MPR Decree No.VI of 1973 concerning the concept of Archipelago Insight and National Security.

- Law No. 29 of 1954 concerning the Principles of Popular Resistance.

- Law No. 20 of 1982 concerning the Basic Provisions for Defense and Security of the Republic of Indonesia. Amended by Law No. 1 of 1988. MPR Decree No. VI of 2000 concerning the Separation of the TNI with the Police.

- Tap MPR No. VII of 2000 concerning the Role of the TNI and Polri.

- Amendments to the 1945 Constitution of the Republic of Indonesia Article 27 paragraph 3 and Article 30 .

- Law No. 3 of 2002 concerning National Defense.

With the same rights and obligations every Indonesian without command must be able to play an active role in carrying out the defense of the country.

Defending a country does not have to be in the form of war but can be realized in other ways such as:

(1) Participating in securing the surrounding environment (such as siskamling);

(2) Participating in helping victims of disasters in the country;

(3) Study diligently on subjects or subjects in Civic Education or PKN;

(4) Participating in extracurricular activities such as Paskibra, PMR and Scouts.

As good citizens, it is appropriate that we participate in defending the country by being aware of and overcoming various threats, challenges, obstacles and disturbances (ATHG) to the Republic of Indonesia. The Unitary State of the Republic of Indonesia (NKRI) is like a hero who is willing to sacrifice for the sovereignty and unity of the Republic of Indonesia.

Defending the country is a necessity and a necessity for all components of the Indonesian nation so that its existence is not to be debated.

Juridically, defending the country has been listed in various legal rules so that its validity is strong. The most important thing now is how to describe the defense of the country in the practice of daily life in society. The defense of the state must manifest in daily life and be reflected in the attitudes and behavior of citizens.

Every behavior of citizens based on state defense must refer to the elements of state defense as follows: Love of the Motherland, National and State Awareness, Confidence in Pancasila as an ideology of the state, willing to sacrifice for the nation and state, and Having the initial ability to defend the country.

Defending the state is always an obligation for every citizen because the state contains citizens who have a mutually beneficial relationship with the state. State defense programs are generally needed by every country because the state is always in the shadow of enemy threats.

In a realist perspective, defending the country is a necessity considering that the international system is anarchic so that each country has the potential to attack other countries so that each country always seeks to increase military power, weaponry and ask for "help" citizens to participate in defending the country when the country is in a state of emergency, emergency war or in a state of war with other countries

Citizens always demand the state to protect its individual interests in society so that the state demands reciprocity by requiring citizens to defend the country when the state is at war or in an emergency situation facing enemy threats. Every behavior of citizens based on state defense must refer to 
the elements of state defense as follows: Love of the Motherland, National and State Awareness, Confidence in Pancasila as an ideology of the state, willing to sacrifice for the nation and state, and Having the initial ability to defend the country.

Defending the state is always an obligation for every citizen because the state contains citizens who have a mutually beneficial relationship with the state. State defense programs are generally needed by every country because the state is always in the shadow of enemy threats.

In a realist perspective, defending the country is a necessity considering that the international system is anarchic so that each country has the potential to attack other countries so that each country always seeks to increase military power, weaponry and ask for "help" citizens to participate in defending the country when the country is in a state of emergency, emergency war or in a state of war with other countries

Citizens always demand the state to protect its individual interests in society so that the state demands reciprocity by requiring citizens to defend the country when the state is at war or in an emergency situation facing enemy threats.

The same thing applies when the government promotes national defense. There are at least eight basic national defense laws in Indonesia.

3. Law Number 56 of 1999 concerning Trained People.

The legal basis for the defense of the state in Indonesia, subsequently, is Law Number 56 Year 1999. This Law regulates in full the trained people. Trained people are the basic elements of the national defense and security forces that are able to carry out the functions of public order, protection of the people, popular security, and popular resistance in the context of implementing national security and defense.

Furthermore, this law regulates the formation and formation of trained people who are the responsibility of the government. The trained people referred to are all citizens aged 18-45 years who are physically and mentally healthy, and are not in a state of losing their right to defend the country. after being fostered, the trained people are given an assignment on the authority of the president. If there is a violation in the matter of defending the country, there is a crime also regulated in this law.

4. Decree of the People's Consultative Assembly Number VI Year 2000 Concerning the Separation of the TNI with the Police.

Before the decree of the Indonesian People's Consultative Assembly No. VI of 2000, there was a bias of power and authority in the world defense and security of this country. The TNI and Polri are united in the ABRI (Indonesian Armed Forces) organization. In addition, ABRI's dual function also occurred in the world of politics and security, so a MPR Decree was formed to overcome this problem.

Tap MPR No. VI of 2000 made ABRI divided into two, namely the TNI and Polri. It was also stressed that the TNI was a tool of the state for national defense, while the National Police was a tool of the state to maintain national security. In maintaining national defense and security, the military and police must cooperate with each other and help each other.

5. Decree of the People's Consultative Assembly No. VII of 2000 concerning the Role of the TNI and Polri. 
As a form of follow up from MPR Decree No. VI of 2000 concerning the separation of the TNI and Polri, the MPR RI once again ratified a Tap relating to the previous Tap, namely Tap No. VII of 2000 concerning the role of the TNI and Polri. This MPR decree was used to emphasize the separation of the TNI from the National Police.

In Article 2 of this Tap, the TNI's main task is to uphold the country's sovereignty, the territorial integrity of the Unitary Republic of Indonesia, and protect the entire nation and the whole of Indonesia's blood spills from threats and disturbances to the integrity of the nation and the state, and to carry out a state obligation for Indonesian citizens. On the other hand, in Article 6 of this Tap it is mentioned that the National Police has a role in maintaining security and public order, enforcing the law, providing cover and service to the community.

6. Amendments to the 1945 Constitution of the Republic of Indonesia Article 30 paragraph (1) through paragraph (5) and Article 27 paragraph (3).

The basic thing of the universal defense of the state is the need for awareness of the defense of the state of all Indonesian citizens from all walks of life. Awareness of national defense has been mandated in Article 27 paragraph (3) of the 1945 Constitution of the Republic of Indonesia which reads "Every citizen has the right and obligation to participate in efforts to defend the country."

Amendments to the 1945 Constitution of the Republic of Indonesia Republic of Indonesia as mentioned above produce a provision that must be followed or the rights and obligations of citizens. In particular, Article 27 paragraph (3) regulates the obligation of citizens to participate in efforts to defend the country. In addition, Article 30 paragraph (1) and paragraph (2) state that citizens have the right and obligation to participate in defense and security efforts through the universal system. Subsequent verses form the basis for the role of the TNI and Polri in national defense and security efforts.

Furthermore, in Article 30 paragraph (1) of the 1945 Constitution of the Republic of Indonesia, it reads "Every citizen has the right and obligation to participate in the National Defense and Security Effort". Further elaboration on the defense of the state is contained in Article 9 of the Law of the Republic of Indonesia Number 3 of 2002 concerning National Defense, which regulates that defending the country is the attitude and behavior of citizens imbued with his love for the Unitary Republic of Indonesia based on Pancasila and the Basic Law (UUD) 1945 in ensuring the survival of the nation and state.

\section{Law Number 3 of 2002 concerning National Defense.}

This law further regulates efforts to defend the country in the context of foreign threats threatening Indonesia's independence. The main actor in this Act is the Indonesian National Army. however, do not forget that citizens are also included in this law because they are entitled and obliged to participate in efforts to defend the state which is realized in the implementation of national defense.

The highest person in charge of national defense according to this Law is the President of the Republic of Indonesia, taking into account the considerations of the House of Representatives. The development of defense capability, supervision and financing for national defense is also regulated in this Law.

As mandated by the 1945 Constitution Article 27 paragraph (3), that every citizen has the right and obligation to participate in efforts to defend the country as well as Law No. 3 of 2002 concerning State Defense Article 9 paragraph (1), that every citizen has the right and obligation to participate in efforts to defend the country, which is explained later by paragraph (2) that one form of organizing the participation of citizens in the effort to defend the country is through training basic military mandatory. 
Several countries in the world implement compulsory military service in response to geopolitical challenges, such as in Singapore, Israel, South Korea and Taipei. However, bearing in mind that Indonesia's geopolitical challenges are quite different, the authors argue that basic military education is needed in a limited way, for the formation of disciplines of the younger generation of Indonesia, meaning that national defense education that needs to be formulated is in the form of national services that have various forms of service according to the needs of the wider community.

In the Indonesian context, there is a series of readiness that must be done to implement a state defense program. The readiness for organizing this state defense covers various aspects, including:

- Juridical readiness / legal umbrella.

This means that the government, in this case the Ministry of Defense, must prepare a juridical aspect in the form of a legal umbrella or legislation governing the process, mechanism and technical procedures for the implementation of state defense. The legal umbrella is in the form of the Law on State Defense, PP on National Defense, Presidential Regulation on State Defense, and various derivative regulations as an elaboration of the regulation of state defense.

The current rules are actually contained in the 1945 Constitution, Law No. 3 of 2002 concerning National Defense and Law No. 34 of 204 concerning TNI. However, the regulation has not yet explained in detail and detailed the technical procedures for defending the country. This is important because the issue of regulation is often questioned by various parties in the community who state that the juridical regulations regarding the implementation of state defense are not yet strong.

Therefore, it is not surprising that some time ago when the Ministry of Defense launched a state defense program in the district / city to produce 100 million state defense cadres in the future, getting protests, rejection and resistance from various groups. The Government and Parliament must sit together to compile, agree on and issue technical regulations on the law on the implementation of national defense. - Human Resources Readiness.

This means that the implementation of state defense requires quality and competence of human resources to become trainers, instructors and trainers who can provide education, training and mentoring to the public about defending the country.

The emphasis of the defense of the state is actually on non-physical aspects, namely attitudes, character, personality, mentality and spirit of nationalism, patriotism and patriotism. Non-physical portion is more in the state defense program which can be said to reach $80 \%$, while the portion of physical training reaches $20 \%$, particularly discipline training, marching training, basic military training, and selfdefense training.

This is certainly different from conscription which emphasizes the portion of $80 \%$ physical training especially military basic training, war training, weapons training, and others. While the portion for non-physical in conscription reaches $20 \%$, mainly the planting of nationalism values, national insight, national security, and patriotism. This certainly requires the quality of human resources both from the TNI and from the civilian to provide physical and non-physical training to participants defending the country.

- Budget Readiness.

This means that the national defense program requires a large budget to support various training, education and technical activities in defending the country, starting from accommodation costs, consumption costs, logistics costs, training costs, pocket money, and other technical costs. 
The budget allocation in the APBN for the Ministry of Defense for the state defense program will not be sufficient to finance all the needs of the state defense program activities in various regions both provincial and district / city. This is certainly a homework for the government to prepare an adequate state defense program budget in the midst of the current economic crisis.

The government, in this case the Ministry of Home Affairs must be able to direct each region, provincial and district / city government to help provide assistance and financial support for the implementation of state defense programs in their respective regions through the APBD so that it is transparent and accountable.

- Infrastructure Readiness.

This means that the implementation of a state defense program requires the need for infrastructure, equipment, logistics and special equipment and other supporting equipment, ranging from lodging / mess, training grounds, places of education and various disciplines and outbound training simulations in other outdoor settings.

During this time, there has indeed been support from the TNI, especially the Army which has Rindam in each Kodam that can be used to hold a state defense training where all participants can be accommodated to get state defense training. However, in each Rindam infrastructure is still minimal and supporting equipment so that it requires various steps to meet the needs of educational infrastructure, training and simulations of defending the country.

- Cultural Readiness (Mind set \& culture set).

This means that the implementation of state defense still experiences pros and cons in the public sphere where not all components of society agree and support the state defense program. There is still a misperception and miscommunication between various groups in viewing, understanding and living the country's defense program.

There are still some people who are suspicious and worried that the state defense program is a tool for the TNI to enter the political sphere. Defending the country is understood as compulsory military service and is authoritarian. This misperception must be quickly anticipated with a variety of socialization, counseling, discussion, dialogue and various seminars to unite perceptions and equate views about the country's defense program. Cultural change, in the form of changing the mind set and culture set of people who were allergic to the military during the New Order era, was indeed not easy, so it had to be intensified so that all components of society supported the country's defense program.

Citizen participation in efforts to deal with or mitigate threats is carried out in the form of a state defense effort:

\section{a) Physical Defense}

The involvement of civilians in national defense efforts is a constitutional right and obligation of every citizen of the Republic of Indonesia. But, as regulated in Law Number 3 of 2002 concerning National Defense and in accordance with the doctrine of the Universal Defense System, the implementation is carried out by the Trained People (Ratih) consisting of various elements such as Student Regiments, People's Resistance, Civil Defense, Mitra Babinsa, CSOs that have participated in Military Basic Education and others. 
Trained People have four functions, namely Public Order, Community Protection, People's Security and People's Resistance. The three functions mentioned first are generally carried out during peacetime or during natural disasters or civil emergencies, where the elements of the Trained People assist the regional government in handling security and public order, while the function of the People's Resistance is carried out in a state of war emergency in which the Trained People is an element of combat assistance for regular TNI troops and is directly involved in the battlefield.

If the state of the national economy has recovered and state finances allow, then it is also possible to consider compulsory military service for eligible citizens as is done in many developed countries in the West. Those who have attended military basic education will be used as a reserve of the Indonesian National Army for a certain period of time, with service periods for example a month in a year to attend refresher training or courses.

In a state of war emergency, they can be mobilized in a short time for combat and territorial tasks. Recruitment is done selectively, regularly and continuously. Placement of duties can be adjusted to their educational background or profession in civilian life such as doctors stationed in the Army Hospital, lawyers in the Legal Service, accountants in the Finance Section, pilots in the Transport Squadron, and so on. It means as an effort to socialize the concept of state defense, in which the task of defense and security of the state is not solely the responsibility of the TNI, but is the rights and obligations of all citizens of the Republic of Indonesia.

According to Law No. 3 of 2002 concerning National Defense, the participation of citizens in defending the country physically can be done by becoming a member of the Indonesian National Army and Basic Military Training. At present the basic military training is organized through the People's Trained (Ratih) program, although the concept of the Trained People (Ratih) is mandated by Law No. 20 of 1982 concerning Principles of National Defense and Security.

Trained People consists of various elements, such as Student Regiment (Menwa), People's Resistance (Wanra), Civil Defense (Hansip), following Military Basic Education and others. Trained People have four functions, namely Public Order, Community Protection, People's Security and People's Resistance. The three functions mentioned first are generally carried out in peacetime or during natural disasters or civil emergencies, where the elements of the Trained People assist the local government in handling Security and Public Order, while the function of the people's resistance is carried out in a state of war where the Trained People is an element of combat assistance for regular TNI troops and is directly involved in the battlefield.

This idea was not intended as an effort to militarize civil society, but to introduce "civilian dual function". That is, as an effort to socialize the "concept of state defense" in which the task of defense and security of the state is not solely the responsibility of the TNI, but is the rights and obligations of all Indonesian citizens.

b) Non-Physical State Defense

As explained earlier that defending the country does not necessarily have to mean "carrying a weapon against an enemy" or defending a militaristic state.

According to Law No. 3 of 2002, the participation of citizens in defending the country nonphysically can be held through civic education and service in accordance with the profession. Based on that, the involvement of citizens in defending the country non-physically can be done in various forms, at all times and in all situations, for example by: 
1. Increase national and state awareness, including living up to the meaning of democracy by respecting differences of opinion and not forcing the will.

2. Instilling love for the motherland, through sincere devotion to the community.

3. Play an active role in advancing the nation and country by creating real work (not rhetoric).

4. Increase awareness and compliance with laws / laws and uphold human rights.

5. Debriefing mentally and spiritually among the community in order to be able to ward off foreign cultural influences that are not in accordance with the norms of the life of the Indonesian people by being more devoted to Allah SWT, through worship according to their respective religions / beliefs.

Until now there is no separate law governing civic education, compulsory military basic training, and service in accordance with the profession as mandated in Law No. 3 of 2002. If later on a law on citizenship education is issued, compulsory military training and service is appropriate to the profession, it will become clearer the form of citizen participation in the defense of the country.

Country Defending Strategies include:

1) Realizing the form of organizing state defense education through civic education education activities, basic military training, serving as a TNI soldier and serving according to the profession. Efforts made include:

a) Citizenship Education. The TNI as the main component provides awareness of defending the country, providing a basic knowledge of defending the country to instill national values.

b) Mandatory military training. Training is conducted for selected communities according to specified requirements. With the hope of material consequences for participants who leave work and their families while attending training.

2) Realizing a system of organizing awareness of the defense of the state through the dissemination of state defense programs to all levels of society. Efforts made include:

a) The relevant ministries and the TNI as the executors of the national defense program manage the implementation of the defense system of the national defense with their respective duties and functions.

b) The Central Government and the Regional Government together with the Ministry of Defense and the TNI conduct campaigns to the public about the rights and obligations of defending the country in accordance with the mandate of the Law and the socialization of the state defense program conducted.

c) Involving social media and mass media to socialize the national defense program.

3) Realizing software that contains laws and regulations that support the implementation of the state defense program. Software is used as a legal umbrella reference in organizing a state defense program.

Efforts made include:

a) The DPR makes rules / legislation related to the obligations and rights of every citizen in the defense of the country.

b) The relevant ministries, the Central Government and the Regional Governments make operational and technical guidelines in implementing state defense programs. This includes the provisions in the implementation of the state defense program.

4) Realizing the budget needed to support the implementation of the state defense program, especially to provide consequences for people who temporarily leave their jobs. 
Based on the strategy to be carried out, it is hoped that the cultivation of awareness of the values of the country's defense can be realized. Good defense skills will guarantee the survival of the nation and state of Indonesia.

State defense is the attitude and behavior of every citizen, imbued with his love for the Unitary State of the Republic of Indonesia based on the Pancasila and the 1945 Constitution in ensuring the survival of the nation and state. Every citizen has the right to participate in the business of state defense and the requirements for defense are regulated by law.

The ability to defend the country is essentially awareness and willingness to serve the country and willingness to sacrifice to defend the country. Therefore, every citizen is directed to have the basic elements of defending the country, in the form of: love for the motherland; national and state awareness; confident of Pancasila as the state ideology; willing to sacrifice for the nation and state; and have the initial ability to defend the country.

Therefore, the formation of a state defense attitude must be carried out as early as possible through a state defense program by fostering a love for the motherland, national and state awareness, willingness to sacrifice for the sake of the nation and state, living and practicing Pancasila so that it has a mental attitude that is aware of rights and its obligations and responsibilities as a citizen.

\section{Conclusion}

Based on the formulation of the problem above and the results of research and discussion, several points that can be concluded include:

1. National Defending Strategy in Strengthening the National Defense System that Can Ensure the Establishment of the Unitary Republic of Indonesia (NKRI):

a. Realizing the form of organizing state defense education through civic education education activities, basic military training, serving as a TNI soldier and serving according to the profession.

b. Creating a system of organizing awareness of the defense of the state through the dissemination of state defense programs to all levels of society.

c. Creating software that contains laws and regulations that support the implementation of the country's defense program. Software is used as a legal umbrella reference in organizing a state defense program.

2. Implementation of State Defending Policy in Strengthening the Unitary State of the Republic of Indonesia (NKRI) Defense System: regulated in Law No. 3 of 2002 concerning National Defense. Where explained that the Defending the State is the attitude and behavior of citizens imbued with his love for the Unitary State of the Republic of Indonesia based on Pancasila and the 1945 Constitution in establishing the survival of the nation and the whole nation. Whereas the defense of the state is the right and obligation of every citizen. Implementation in Article 9 paragraph (2) of Law Number 3 of 2002 explains that efforts to defend the country can be carried out through: Citizenship Education, compulsory military basic training, Service as a soldier of the Indonesian National Army voluntarily or compulsorily, and Dedication according to the profession. 


\section{Suggestion}

1. To the Government in this matter the Ministry of Defense is recommended to be more vigorous to disseminate to the public the importance of defending the country, so that the community is able to grow and foster awareness and willingness to the state.

2. Regarding the legal substance, providing citizenship education to citizens through the Pancasila Living and Living Guidelines so that Indonesian citizens understand that they are brothers and sisters so as to strengthen national unity and integrity by eliminating horizontal conflicts due to various kinds of differences.

\section{References}

Abudin Nata, Islamic Study Methodology, (Jakarta: Raja Grafindo Persada, 2003)

Agus Subagyo, Defending the Nation: "Opportunities and Order in the Era of Globalization", (Yogyakarta: Graha Science, 2015)

Alex Suseno, Culture Strategy for Awareness of State Defense 2000-2004, (Jakarta: Pustaka Sinar Harapan, 2000)

Amin Arjoso. Pancasila Basic Philosophy of the State. (Jakarta: Yayasan Kepada Bangsaku. 2000)

AM.Hendropriyono, Philosophy of State Intelligence of the Republic of Indonesia, (Jakarta: Gudang Publisher, 2013)

Bahder Johan Nasution, Legal Science Research Methods, (Bandung: Mandar Maju, 2008)

Budimansyah, Let's Participate in Defending the Country, (Bandung: Ganesindo, 2006)

Cholisin Main Material: Citizenship Science-Citizenship Education. (Yogyakarta: UNY. 2000)

Chotib and Djazuli, Attitudes of Nationalism. (Jakarta: Bumi Citra, 2007)

Erwin A. Pohe, Collection of Posts Hacking Brotherhood in Diversity, (Jakarta: PT. Pustaka Sinar Harapan, 2012)

Gearoid Ó Tuathail, Geopolitics Reader, (routledge, 2006)

Hamid Darmadi, Introduction to Citizenship Education. (Bandung: Alfabeta. 2010)

Hans J. Morgenthau, Politics Among Nations: The Strugle for Power and Peace, (London: Willey Press, 1990)

Hans Kohn, Nationalism's Meaning and History, (Jakarta: Erlangga, 1984)

Isworo Hadi Wiyono, Nationality for Middle School, (Bandung: Ganeca, 2007)

John Locke, Second Treatise of Government, (Hackett Publishing Company, 1980) 
Kaelan Pancasila Education Reform Edition, (Yogyakarta: MS. Paradigm, 2010)

Kaelan, Citizenship Education for Higher Education, (Yogyakarta: PARADIGMA. 2010

Lemhanas, Citizenship Education, (Jakarta: Pustaka Setia, 2000)

Mechel Mingst, The Filoshopy of Nationality and Identity, (London: Wesbrom Press, 2007)

Moh.Mahfud Md, Building Political Law, Upholding the Constitution, (Jakarta: Rajawali Press, 2010)

Moh.Mahfud Md, Legal politics in Indonesia, (Jakarta: LP3ES. 1998)

Notonagoro, Basic Pancasila of State Philosophy, (Jakarta: Bina Aksara, 1984)

Nur Wahyu Rochmadi, Nationality. (Jakarta: Yudhistira. 2007)

Pratiwi Nur, Book of National Defense Review, (Bandung: Gramedia, 2015)

Retno Listyarti. Civic education. (Jakarta: Esis. 2007)

Roni Lukum, Efforts to Increase Understanding of the Archipelago's Insight as a Means in Enhancing the Spirit of Nationalism for Indonesian Citizens, "(Gorontalo State University, 2005)

R.M. Sunardi, Guidance for National Resilience, in the context of strengthening the integrity of the Unitary State of the Republic of Indonesia. (Jakarta: PT Kuadernita Adidarma, 2004)

Soejono Soekanto, Introduction to Legal Research, (Jakarta: UI Press, Jakarta, 1986)

Suharsimi Arikunto, Research Procedure, a Practice Approach, (Jakarta: Rineka Cipta, 2002)

Sumarsono, et al. Citizenship Education, (Jakarta: Gramedia Pustaka Utama, 2005)

Surayin, Indonesian General Dictionary, Analysis, (Bandung: Yrama Widya, 2001)

Trianto and full stop. State Philosophy and Citizenship Education. (Jakarta: Literature Achievements. 2007)

Widoyo Alfandi, Indonesian Reform: Discussion from the Geogradi and Geopolitical Perspectives. (Yogyakarta: Gadjah Mada University, 2002)

Winarno. Citizenship Education Learning. (Jakarta: Earth Literacy, 2013)

Winarno. Public Policy: Theory and Process. (Yogyakarta: Med Press, 2007)

Winarno. New Paradigm of Citizenship Education, (Jakarta: PT Bumi Aksara, 2007)

Constitution

Law Number 29 of 1954 concerning Principles of Popular Resistance

Law Number 20 of 1982 concerning Basic Provisions for the Defense and Security of the Republic of Indonesia 
Law Number 39 of 1999 concerning Human Rights

Law Number 56 of 1999 concerning Trained People

Law Number 3 of 2002 concerning National Defense

Presidential Regulation Number 97 of 2015 concerning General Policy for National Defense 2015-2019

Decree of the People's Consultative Assembly Number VI Year 2000 Concerning the Separation of the TNI with the Police

Decree of the People's Consultative Assembly No. VII of 2000 concerning the Role of the TNI and Polri

\section{Copyrights}

Copyright for this article is retained by the author(s), with first publication rights granted to the journal.

This is an open-access article distributed under the terms and conditions of the Creative Commons Attribution license (http://creativecommons.org/licenses/by/4.0/). 